\title{
ANALISIS PENERAPAN SISTEM DAN PROSEDUR PEMBERIAN KREDIT PEMILIKAN RUMAH (KPR) SUBSIDI PADA BANK TABUNGAN NEGARA CABANG MANADO
}

\author{
Hibatullah Fauzan Takalamingan ${ }^{1}$, David P.E. Saerang ${ }^{2}$, Meily Y.B Kalalo ${ }^{3}$ \\ 1,2,3 Jurusan Akuntansi, Fakultas Ekonomi dan Bisnis, Universitas Sam Ratulangi, Jl. Kampus Bahu, Manado, \\ 95115, Indonesia \\ E-mail : Fauzant31@gmail.com
}

\begin{abstract}
This study aims to find out how the System and Procedure of the Subsidy House Ownership Credit (KPR) in Manado Branch of PT. Bank Tabungan Negara. This type of research is descriptive with qualitative approach. The data collecting techniques done were interview, observation and documentation. The steps taken to analyze the acquired data were done in two phases, they were (1) analyzing how the System and Procedure of the Subsidy House Ownership Credit (KPR) in Mandao Branch of PT. Bank Tabungan Negara (BTN) is already good, and (2) analyzing whether the factors that cause bad credit in the House Ownership Credit (KPR) in Manado Branch of PT. Bank Tabungan Negara and how the settlement of bad credit is done by the Manado Branch of PT. Bank Tabungan Negara. The result of the research showed that the Subsidy House Ownership Credit (KPR) System and Procedure were good and was suitable with the standards applied by the government. Factors that cause bad credit in the House Ownership Credit (KPR) System and Procedure in Manado Branch of PT. Bank Tabungan Negara were ill debtors, the debtor has no job, the house is not standard, and the character of the debtor. The settlement effort is to collect and if it cannot be billed then a decision is taken by auction.
\end{abstract}

Keywords: System and Procedure, the Subsidy House Ownership Credit, and Bad Credit.

\section{PENDAHULUAN}

Pada era ini pemerintah lebih menekankan untuk memajukan kesejahteraan rakyat, terlebih khusus untuk rakyat yang mempunyai penghasilan rendah, karena penghasilan rendah ini termasuk posisi yang paling banyak terdapat di Indonesia sekarang ini. Salah satu program pemerintah saat ini berfokus untuk lebih memajukan kesejahteraan rakyat yang mempunyai penghasilan rendah, dengan melakukan pembangunan pada sektor perumahan yang layak untuk dihuni dan telah sesuai ketentuan.

Kredit Pemilikan Rumah (KPR) Subsidi yaitu kredit yang ditawarkan oleh bank dan juga termasuk bagian dari program pemerintahan. Adapun yang akan dikenakan subsidi adalah suku bunga kredit atau uang muka. Berdasarkan Undang-Undang No. 1 Tahun 2011 tentang Perumahan dan Kawasan Permukiman, masyarakat berpenghasilan rendah mendapatkan dukungan kepemilikan rumah melalui kebijakan kemudahan dan/atau bantuan pembangunan dan perolehan rumah. Terkait kemudahan dan/atau bantuan pembangunan dan perolehan rumah tersebut selanjutnya diatur dalam sebuah peraturan menteri yaitu Peraturan Menteri Pekerjaan Umum (PU) Rakyat Republik Indonesia Nomor 21/PRT/M/2016. Sistem dan prosedur pemberian Kredit Pemilikan Rumah (KPR) Subsidi pada Bank Tabungan Negara Cabang Manado diatur oleh pihak Bank Tabungan Negara.

KPR Subsidi mempunyai suatu masalah yaitu timbulnya penunggakan pembayaran angsuran yang dapat menyebabkan kredit macet. Hal ini disebabkan oleh faktor intern dan faktor ekstern, faktor intern yaitu pihak bank, sedangkan faktor ekstern yaitu pihak debitur. Faktor intern biasanya terjadi karena kelalaian dari pihak bank, sedangkan faktor ekstern 
terjadi karena kesengajaan yang dilakukan pihak debitur atau biasanya saat sudah melakukan kredit pihak debitur mengalami kondisi penurunan keuangan sehingga yang awalnya mampu untuk menyetor tagihan sekarang tidak lagi mampu.

Sistem pemberian Kredit Pemilikan Rumah (KPR) Subsidi yang selama ini digunakan oleh Bank Tabungan Negara cabang Manado yaitu terdiri dari unsur sistem pemberian KPR Subsidi, syarat KPR Subsidi, dokumen pengajuan KPR Subsidi dan fungsi yang terkait dalam pemberian Kredit Pemilikan Rumah Subsidi. Adapun Prosedur pemberian Kredit Pemilikan Rumah yang digunakan oleh Bank Tabungan Negara cabang Manado yaitu terdiri dari prosedur permohonan dan pengajuan Kredit Pemilikan Rumah Subsidi, prosedur keputusan dan permohonan Kredit Pemilikan Rumah Subsidi, prosedur realisasi, dan prosedur pembayaran dan pelunasan Kredit Pemilikan Rumah (KPR) Subsidi.

\section{TINJAUAN PUSTAKA}

Konsep Akuntansi. Menurut Krismiaji (2015:15) definisi akuntansi adalah suatu cara atau metode pendataan, pengelompokkan, peringkasan, pengikhtisaran, penyajian pelaporan dari seluruh transaksi keuangan dalam perusahaan. Sedangkan Horngren et al., yang dikutip oleh Pontoh (2013:1) berpendapat bahwa akuntansi merupakan suatu sistem informasi untuk mengukur aktivitas bisnis, memproses data untuk dijadikan laporan, dan mengkomunikasikan hasil bagi para pengambil keputusan.

\section{Sistem dan Prosedur}

Definisi Sistem dan Prosedur. Menurut Mulyadi (2016:2), sistem yaitu suatu kelompok unsur yang saling berhubungan satu sama lain, yang fungsinya bersama-sama untuk mencapai suatu tujuan. Menurut Romney dan Steinbart (2015:3) Sistem merupakan serangkaian dari dua atau lebih komponen yang saling berhubungan satu sama lain untuk mencapai tujuan tertentu. Sedangkan Mulyadi (2016:5) berpendapat bahwa prosedur yaitu suatu aktivitas klerikal, yang menyangkut sebagian orang di dalam suatu perusahaan atau bisa saja lebih, yang dibentuk untuk menjamin penanganan secara seragam suatu transaksi perusahaan yang terjadi berulang kali.

Karakteristik Sistem. Menurut Latdjamudin (2013:3) Karakteristik sistem adalah sebagai berikut: komponen sistem, batasan sistem, lingkungan luar sistem, penghubung sistem, masukan sistem, keluaran sistem, pengolahan sistem, dan sasaran sistem.

Klasifikasi Sistem. Menurut Susanto (2013:30) Klasifikasi sistem adalah sebagai berikut ini: sistem tertutup dan terbuka, sistem alamiah, sistem berjalan dan konseptual, sistem sederhana dan komplek, kinerjanya dapat dan tidak dapat dipastikan, selamanya dan sementara, ada secara phisik dan abstrak/non phisik, sistem, subsistem dan supersistem, dan bisa beradaptasi dan tidak bisa beradaptasi.

Sistem Akuntansi Pemberian Kredit. Sistem Akuntansi Pemberian Kredit merupakan sebuah sistem yang terdiri dari sekumpulan unsur yang saling berkaitan satu sama lain, maka sistemnya bisa dijadikan pengelola data yang berkaitan dengan tindakan sebuah perusahaan, memicu berlangsungya pemberian kredit seperti dokumen, pencatatan, prosedur dan bagian yang berkaitan dengan tujuan untuk menghasilkan suatu laporan yang diperlukan pihak manajemen.

Fungsi yang terkait dalam Pemberian Kredit. Menurut Mulyadi (2016:487) dalam sistem akuntansi pemberian kredit terdapat fungsi-fungsi yang berkaitan di dalamnya, yaitu : fungsi sekretariat, fungsi penagihan, fungsi kas, fungsi akuntansi, dan fungsi pemeriksaan intern.

Dokumen yang terkait dalam Pemberian Kredit. Mulyadi (2016:3) berpendapat bahwa dokumen yaitu sebuah kertas yang berguna untuk mendokumentasikan transaksi awal perusahaan untuk dijadikan dasar pencatatan. Berikut ini beberapa dokumen yang digunakan 
pada sistem pemberian kredit: lembar isian pemohon kredit, kwitansi, bukti pengeluaran kas, bukti penerimaan kas, dan kartu pinjaman.

Catatan Akuntan yang terkait dalam Pemberian Kredit. Mulyadi (2016:4) berpendapat bahwa catatan akuntansi yang dipakai dalam sistem akuntansi pemberian kredit yaitu catatan akuntasi yang dipakai untuk mencatat, mengklasifikasi serta menyimpulkan informasi keuangan dan informasi lainnya. Catatan yang digunakan dalam sistem pemberian kredit yang di kutip pada artikel Bizfluent adalah : buku besar, aplikasi akuntansi pinjaman, aplikasi rekening nasabah, dan aplikasi internet banking.

\section{Kredit}

Definisi Kredit. Menurut Thomas dalam Ismail (2013:93) kredit dalam pengertian umum merupakan kepercayaan atas kemampuan pihak debitur (penerima kredit) untuk membayar sejumlah uang pada masa yang akan datang.

Unsur-unsur Kredit. Beberapa unsur yang terkandung dalam setiap pemberian fasilitas kredit. Menurut Kasmir (2014:87) menyatakan bahwa unsur-unsur yang terkandung dalam pemberian fasilitas kredit yaitu: kepercayaan, kesepakatan, jangka waktu, risiko, dan balas jasa.

\section{Tujuan dan Fungsi Kredit}

1. Tujuan Kredit. Dalam pemberian suatu fasilitas kredit mempunyai tujuan-tujuan tertentu. Adapun tujuan pemberian kredit menurut Kasmir (2014:88) adalah sebagai berikut: mencari keuntungan, membantu usaha nasabah, dan membantu pemerintah.

2. Fungsi Kredit. Menurut Kasmir (2014:89), sebuah alat kredit memiliki fungsi sebagai berikut: berfungsi menambah daya guna, berfungsi menambah peredaran uang, berfungsi menambah kegunaan suatu barang, menambah peredaran suatu barang, sebagai media penyeimbang ekonomi, berfungsi menambah rasa ingin berusaha, berfungsi untuk meningkatkan keseimbangan pendapatan, dan berfungsi meningkatkan ikatan antar internasional.

Jenis-jenis Kredit. Menurut Kasmir (2014:90) beberapa jenis kredit bisa dilihat dari beberapa segi antara lain, yaitu:

1. Dari segi kegunaan kredit : Kredit Investasi, dan Kredit Modal Kerja.

2. Dari segi tujuan kredit : Kredit Produktif, Kredit Konsumtif, dan Kredit Perdagangan.

3. Dari segi jangka waktu kredit: Kredit Jangka Pendek, Kredit Jangka Menengah, dan Kredit Jangka Panjang.

4. Dari Segi Jaminan :: Kredit dengan jaminan, dan Kredit tanpa jaminan.

5. Dari segi sektor usaha : Kredit Pertanian, Kredit Peternakan, Kredit Industri, Kredit Pertambangan, Kredit Pendidikan, Kredit Profesi, dan Kredit Perumahan.

\section{Kredit Pemilikan Rumah}

Definisi Kredit Pemilikan Rumah (KPR). Kredit Pemilikan Rumah (KPR) adalah kredit yang digunakan untuk membeli rumah atau kebutuhan konsumtif lainnya dengan jaminan/agunan berupa rumah. Kredit Pemilikan Rumah yaitu suatu jenis layanan kredit yang diberikan pihak bank kepada pihak debitur yang ingin meminjam pinjaman khusus untuk bisa mencukupi kebutuhan pembangunan rumah.

Jenis-jenis Kredit Pemilikan Rumah (KPR). Di Indonesia sendiri, saat ini dikenal ada 2 jenis KPR : KPR Subsidi, dan KPR Non Subsidi.

Komponen Utama Kredit Pemilikan Rumah (KPR). Komponen utama Kredit Pemilikan Rumah (KPR) yaitu: Kreditur KPR, Debitur KPR, Objek KPR, dan Jangka waktu KPR.

Kredit Macet. Ikatan Bankir Indonesia (2015:91) berpendapat bahwa ada berbagai pengertian kredit macet atau kredit bermasalah:

1. Kredit yang pada kegiatannya belum sesuai sasaran yang direncanakan pihak bank. 
2. Kredit yang mempunyai risiko bagi pihak bank pada masa yang akan datang dalam artian luas.

3. Kredit yang terdapat kesulitan pada penyelesaiannya, dalam pengembalian pokok atau pembayaran bunga, denda atas keterlambatan pembayaran, dan ongkos-ongkos bank yang membebankan pihak debitur.

4. Kredit yang pada pembayaran kembalianya pada tahap bahaya, terlebih khusus jika sumber pembayaran kembalian yang diharapkan tidak mampu untuk melunasi kembaliannya kemudian belum tercapainya sasaran yang direncanakan pihak bank.

5. Kredit yang cacat pada pembayaran kembaliannya sehingga menjadi penunggakan, atau mengakibatkan kerugian pada pihak perusahaan debitur sehingga berkemungkinan timbulnya risiko pada masa yang akan datang bagi pihak bank dalam arti luas.

6. Kredit yang sulit penyelesaiannya terhadap bank, dalam pengembalian pokok, pembayaran bunga ataupun pembayaran ongkos-ongkos yang membebankan pihak debitur yang terkait.

7. Kredit yang termasuk pada bagian perhatian khusus, tidak lancar, tidak dapat dipercaya, dan macet serta termasuk bagian lancar namun berisiko menunggak.

Pengendalian Internal. Untuk mencapai tujuan utama, setiap perusahaan wajib mempunyai sebuah sarana yang bisa dijadikan kontrol atas kinerja dan sistem yang ada pada perusahaan. Sarana tersebut yaitu Pengendalian Internal (Internal Control). Pengendalian Internal yaitu cara yang dilakukan pihak perusahaan untuk menurunkan risiko kecurangan yang bisa saja terjadi pada sebuah sistem yang ada dalam perusahaan.

Tujuan Pengendalian Internal. Menurut Arens dkk (2015:340), yang dijadikan sasaran pengendalian internal di suatu perusahaan adalah sebagai berikut : Reliability of Financial Reporting (Keandalan Laporan Keuangan), Efficiency and Effectiveness of Operation (Operasi yang Efektif dan Efisien), dan Compliance with Applicable Laws and Regulation (Ketaatan pada Hukum dan Peraturan).

Unsur-unsur Pengendalian Internal. Komponen pengendalian internal menurut Commite of Sponsoring of Organization (COSO) dalam Internal Control - Intergrated Framework (2013:6-7), pengendalian internal terdapat 5 komponen yang berhubungan satu sama lain, yaitu : Lingkungan Pengendalian (Control Environment), Penilaian Resiko (Risk Assesment), Aktivitas Pengendalian (Control Activities), Informasi dan Komunikasi (Information and Communication), dan Aktivitas Pemantauan (Monitoring Activities).

Kajian Penelitian Terdahulu. Satria (2018) melakukan penelitian dengan judul analisis perbandingan pemberian Kredit Pemilikan Rumah (KPR) pada Bank Konvesional dengan pembiayaan Murabahah (KPR) pada Bank Syariah (Studi kasus pada Bank BJB dengan Bank BJB Syariah). Penelitian ini dilakukan untuk mengetahui perbedaan sistem pembiayaan kredit perumahan oleh Bank Jabar Banten (BJB) dan Bank Jabar Syariah sebagai sampel. Metode penelitian yang digunakan adalah metode komparatif. Hasil dari penelitian ini menyimpulkan bahwa perbandingan pemberian kredit pada Bank Konvesional BJB dengan pembiayaan murabahah pada Bank BJB Syariah memiliki banyak persamaan dalam prosedur dan berkas persyaratan. Hanya saja pada aspek akad atau perjanjian mempunyai perbedaan. Pada Bank Konvesional sepenuhnya menggunakan sistem bunga, sedangkan pada Bank Syariah menerapkan akad murabahah dengan sistem bagi hasil dari keuntungan jasa dan transaksi riil.

\section{METODE PENELITIAN}

Jenis Penelitian. Jenis penelitian pada penelitian ini adalah penelitian kualitatif yang menggunakan pendekatan deskriptif. Penelitian ini menggambarkan keadaan yang akan diteliti secara mendalam, terlebih khusus dalam sistem dan prosedur pemberian Kredit Pemilikan Rumah (KPR) subsidi pada Bank Tabungan Negara Cabang Manado. 
Tempat dan Waktu Penelitian. Penelitian ini akan dilaksanakan pada Bank Tabungan Negara Cabang Manado yang beralamat di Jalan Wolter Monginsidi No. 56 Bahu. Waktu penelitian direncanakan akan di mulai pada bulan September tahun 2018 sampai selesai.

Jenis Data Penelitian. Jenis data penelitian yang digunakan yaitu data kualitatif. Data kualitatif pada penelitian ini yaitu mengenai sejarah, visi dan misi, struktur organisasi, sistem dan prosedur pemberian kredit pemilikan rumah (KPR) subsidi pada Bank Tabungan Negara Cabang Manado.

Sumber Data Penelitian. Sumber data penelitian yang digunakan dalam penelitian ini adalah data primer. Sumber data primer berupa sejarah Bank, tujuan Bank, visi misi Bank, struktur organisasi Bank, sistem dan prosedur pemberian Kredit Pemilikan Rumah (KPR) Subsidi Bank. Sumber data primer dalam penelitian ini dilakukan melalui wawancara, observasi, dan dokumentasi pada Bank Tabungan Negara Cabang Manado.

Metode Pengumpulan Data. Terdapat tiga metode pengumpulan data penelitian yang dipakai pada penelitian ini, yaitu : Wawancara, Observasi, dan Dokumentasi.

Metode dan Proses Analisis. Metode analisis data pada penelitian ini adalah metode analisis deskriptif. Metode ini mempunyai tujuan untuk memberikan gambaran perusahaan, menguraikan serta membandingkan dan juga menerangkan sesuatu data kemudian dianalisis, sehingga dapat menghasilkan kesimpulan berdasarkan informasi dan data-data yang sudah diperoleh. Proses analisis pada penelitian ini, yaitu:

1. Pertama, memperoleh data-data dari Bank Tabungan Negara Cabang Manado dalam hal ini yaitu langkah pertama untuk memahami keadaan perusahaan khususnya keadaan sistem dan prosedur pemberian kredit pemilikan rumah (KPR) subsidi dari perusahaan itu sendiri.

2. Langkah selanjutnya penulis membahas akan data-data yang telah dikumpulkan, melihat bagaimana penerapan sistem dan prosedur pemberian kredit pemilikan rumah (KPR) subsidi yang dilakukan oleh Bank.

3. Kemudian penulis mengambil kesimpulan dari bahasan yang telah dilaksanakan pada tahap-tahap sebelumnya.

4. Tehap terakhir dalam proses ini yaitu memberi saran apabila menemukan suatu yang harus dibetulkan pihak Bank, supaya bisa menjadi lebih baik dari sebelumnya.

\section{HASIL PENELITIAN DAN PEMBAHASAN}

\subsection{Hasil Penelitian}

Produk Kredit Bank Tabungan Negara. Adapun produk-produk kredit yang ditawarkan Bank Tabungan Negara Cabang Manado adalah sebagai berikut : KPR BTN Subsidi, KPR BTN Platinum, Kredit Pemilikan Apartemen (KPA), Kredit Ruko, Kredit Agunan Rumah (KAR), Kredit Bangun Rumah (KBR), Kredit Swadana, Kredit Ringan, Kredit Ringan Pensiunan, KMK Konstruksi, Kredit Linkage, Kredit Pemilikan Lahan, Kredit Investasi, Kredit Modal Kerja, Kredit Usaha Mikro dan Kecil, dan Kredit Modal Kerja Kontraktor.

Kredit Pemilikan Rumah (KPR) Subsidi. Kredit Pemilikan Rumah (KPR) Subsidi adalah Kredit Pemilikan Rumah (KPR) yang dibuat pihak Bank dan merupakan salah satu program dari pemerintah, untuk dijadikan fasilitasi dalam pembelian rumah sederhana bagi rakyat yang mempunyai penhasilan rendah. Adapun yang akan dikenai subsidi yaitu beban bunga atau uang muka. Berdasarkan Undang-Undang No. 1 Tahun 2011 tentang Perumahan dan Kawasan Pemukiman, masyarakat berpenghasilan rendah mendapatkan dukungan kepemilikan rumah melalui kebijakan kemudahan dan/atau bantuan pembangunan dan perolehan rumah. Terkait kemudahan dan/atau bantuan pembangunan dan perolehan rumah tersebut selanjutnya diatur dalam sebuah peraturan menteri yaitu Peraturan Menteri Pekerjaan Umum dan Perumahan Rakyat Republik Indonesia Nomor 21/PRT/M/2016 tentang 
Kemudahan dan/atau Bantuan Perolehan Rumah Bagi Masyarakat Berpenghasilan Rendah. Pada Peraturan Menteri tersebut diatur beberapa hal, diantaranya adalah : kemudahan dan/atau bantuan perolehan rumah, fasilitas likuiditas pembiayaan perumahan, subsidi bunga kredit perumahan, subsidi bantuan uang muka, pemanfaatan rumah sejahtera tapak dan satuan rumah sejahtera susun, dan pengembalian kemudahan dan/atau bantuan perolehan rumah.

Sistem Kredit Pemilikan Rumah (KPR) Subsidi. Unsur sistem pemberian Kredit Pemilikan Rumah (KPR) subsidi pada Bank Tabungan Negara cabang Manado terdiri dari:

1. Fungsi yang terkait: Retail Service Section Head, Loan Service Unit, Teller Service, Branch Manager, dan Accounting Control.

2. Dokumen yang digunakan: Daftar Usulan Pemohon (DUP), Surat Penolakan, Surat Penegasan Persetujuan Pemberian Kredit (SP3K), Surat Persetujuan Debitur Rangkap Lima (SPD5), Surat Perjanjian Kredit, Sistem Informasi Debitur (SID), Formulir permohonan kredit perorangan, dan Dokumen sebagai syarat-syarat kelengkapan data.

3. Catatan akuntansi yang digunakan : Buku Register, Sistem Layanan Informasi Keuangan (SLIK), Sistem E-Loan, dan Sylvester Integrated Banking System (SIBS).

Syarat Kredit Pemilikan Rumah (KPR) Subsidi. Syarat-syarat yang wajib dipenuhi pihak calon debitur untuk pengajuan Kredit Pemilikan Rumah (KPR) subsidi adalah : Warga Negara Indonesia, memiliki E-KTP, tidak memiliki rumah, belum pernah memperoleh subsidi perolehan rumah berupa pemilikan rumah dari pemerintah, memiliki NPWP, memiliki SPT tahunan, dan memiliki penghasilan dibawah Rp.4.000.000,00.

Dokumen Pengajuan Kredit Pemilikan Rumah (KPR) Subsidi. Adapun dokumen yang wajib dipenuhi pihak calon debitur dalam pengajuan kredit pemilikan rumah (KPR) subsidi adalah sebagai berikut : Dokumen pemohon, Dokumen Penghasilan (pemohon pegawai), Dokumen khusus pemohon wiraswasta/pekerja mandiri, Surat pernyataan debitur, Berita Acara Serah Terima (BAST) rumah sejahtera tapak/ rumah satuan sejahtera susun, Surat pernyataan prasarana, sarana, dan utilitas perumahan, Dokumen permohonan SBUM, Surat pernyataan penyelesaian prasarana,sarana, dan utilitas perumahan, Surat pemesanan rumah (SPR), Laporan Pemeriksaan Akhir (LPA), Foto dokumentasi akad kredit pemohon KPR BTN bersubsidi, Foto dokumentasi stiker atau print KPR BTN bersubsidi telah terpasang, Lampiran 1 surat pernyataan tanggung jawab terhadap kualitas bangunan oleh pemegang, Lampiran 2A hasil verifikasi rumah dan PSU rumah subsidi oleh BTN, dan Lampiran 3 surat pernyataan pemeriksaan kelayakan fungsi bangunan gedung oleh pengembang.

Prosedur Kredit Pemilikan Rumah (KPR) Subsidi. Prosedur pemberian kredit pemilikan rumah (KPR) subsidi pada Bank Tabungan Negara (Persero) cabang Manado terdiri dari: Prosedur permohonan dan pengajuan KPR Subsidi, Prosedur Keputusan atas Permohonan Kredit, Prosedur Realisasi, Prosedur Pembayaran Angsuran dan Pelunasan, dan Pembayaran angsuran KPR bisa dilakukan dengan 6 cara, yaitu: (a) Pembayaran angsuran dipotong langsung dari gaji, (b) Pembayaran langsung ke loket BTN, (c) Pembayaran melalui ATM Batara, (d) Pembayaran dengan transfer, (e) Pembayaran melalui kantor pos, dan (f) Pembayaran dengan cara pemindahbukuan

\section{Kredit Macet}

1. Faktor-Faktor Penyebab Terjadinya Kredit Macet. Faktor-faktor yang menjadi penyebab kredit macet pada Kredit Pemilikan Rumah (KPR) subsidi Bank Tabungan Negara adalah sebagai berikut: (a) Debitur Sakit, (b) Debitur sudah tidak memiliki pekerjaan, (c) Rumah tidak standar, dan (d) Karakter debitur.

2. Upaya Penyelesaian Kredit Macet. Adapun upaya yang dilakukan Bank Tabungan Negara untuk menyelesaikan kredit macet yang terjadi pada Kredit Pemilikan Rumah (KPR) subsidi adalah sebagai berikut: (a) Penagihan, dan (b) Lelang. 


\subsection{Pembahasan}

Analisis Sistem dan Prosedur Pemberian Kredit Pemilikan Rumah (KPR)

Subsidi. Pada Bank Tabungan Negara cabang Manado dalam pemberian Kredit Pemilikan Rumah (KPR) Subsidi tidak ada prioritas utama yang dilihat dari segi pekerjaan karena target dari pemberian Kredit Pemilikan Rumah (KPR) Subsidi ini yaitu untuk memberikan rumah layak tinggal bagi seluruh masyarakat yang berpenghasilan rendah sehingga masyarakat bisa mendapatkan fasilitas rumah sebagai tempat tinggalnya. Jadi, bagi setiap warga negara Indonesia dengan pekerjaan apa saja dapat mengajukan permohonan Kredit Pemilikan Rumah (KPR) Subsidi pada Bank Tabungan Negara hanya perlu dengan mengikuti syaratsyarat yang telah ditentukan oleh Bank Tabungan Negara, syarat-syaratnya adalah harus berwarga negara Indonesia, harus memiliki e-KTP, tidak memiliki rumah atau belum pernah memiliki rumah sendiri, belum pernah mengajukan atau memperoleh rumah subsidi dari pemerintah, harus memiliki NPWP, memiliki SPT tahunan, dan memperoleh penghasilan di bawah Rp.4.000.000,00 dan memiliki penghasilan minimal Rp.2.500.000,00 Dengan syaratsyarat ini debitur sudah bisa memiliki rumah yang layak untuk tinggal. Berdasarkan data yang di dapat oleh peneliti dalam penelitian tentang Kredit Pemilikan Rumah (KPR) Subsidi pada Bank Tabungan Negara Cabang Manado yang di dapat dari bagian Loan Service serta hasil wawancara dengan Bapak Vincentius Manoppo. Data tersebut diolah untuk membahas tujuan dari penelitian yaitu bagaimana Sistem dan Prosedur pemberian Kredit Pemilikan Rumah (KPR) Subsidi pada Bank Tabungan Negara Cabang Manado. Sistem dan prosedur pemberian Kredit Pemilikan Rumah (KPR) Subsidi yang dilaksanakan Bank Tabungan Negara Cabang Manado meliputi fungsi yang terkait, dokumen yang digunakan, catatan akuntansi yang digunakan, dan prosedur yang digunakan.

1. Fungsi yang terkait. Dalam pelaksanaan proses pemberian kredit harus melewati beberapa bagian yang terpisah menurut struktur organisasi agar bisa merealisasikan kredit. Berdasarkan data yang diperoleh dari penelitian ini pada prosedur pemberian Kredit Pemilikan Rumah (KPR) Subsidi yang dilaksanakan Bank Tabungan Negara Cabang Manado telah terpisah antara fungsi operasi, fungsi penyimpanan, dan fungsi akuntansi. Fungsi operasi dilaksanakan oleh Branch Manager, Loan Service dan Kasie Retail Service. Fungsi penyimpanan dokumen dilakukan oleh Kasie Retail Service. Fungsi Akuntansi dilakukan oleh Bookkeeping and Control Unit dibawah Accounting and Control Unit. Dengan adanya pemisahan fungsi ini membuat proses pemberian kredit menjadi lebih baik.

2. Dokumen yang digunakan. Dalam pelaksanaanya semua dokumen bernomor urut cetak sehingga dapat memudahkan pengarsipan dokumen. Dan juga dokumen ini tersimpan pada sistem E-loan yang mudah diakses tanpa harus melihatnya di bagian Loan Document.

3. Catatan akuntansi yang digunakan. Catatan Akuntansi yang digunakan dalam sistem akuntansi pemberian Kredit Pemilikan Rumah (KPR) Subsidi banyak menggunakan sistem, seperti petugas bookepping and control hanya mengentri saja dan jurnal akan otomatis muncul di dalam sistem E-Loan. Mengecek data BI Checking di sistem IDeb SLIK dan mengecek rekening debitur pada Sylvester Intergrated Banking System (SIBS), sistem ini terdiri dari jurnal umum, buku besar dan neraca.

4. Prosedur pemberian kredit

a. Permohonan dan Pengajuan Kredit Pemilikan Rumah (KPR) Subsidi. Proses permohonan dan pengajuan kredit dilaksanakan pada bagian Loan Service. Pada pelaksanaannya Loan Service melakukan wawancara kepada debitur, mengisi buku register, mengecek data BI Checking di IDeb SILK, dan menginput data pribadi calon debitur pada sistem E-loan, dan bagian Data Entry Operational melengkapi data calon 
debitur pada E-loan. Dari proses yang dilaksanakan ini, untuk menginput data nasabah sebaiknya di lakukan oleh satu bagian agar bisa lebih efektif lagi.

b. Prosedur Keputusan atas Permohonan Kredit Pemilikan Rumah (KPR) Subsidi. Dalam pengambilan keputusan atas permohonan kredit dilakukan oleh Branch Manager dalam RKK dengan menggunakan hasil wawancara, konfirmasi gaji dan $B I$ Checking yang dilakukan Loan Service. Proses ini sesuai dengan tingkatan pengambilan keputusan kredit dan kreditnya bisa terjamin.

c. Prosedur Realisasi Kredit Pemilikan Rumah (KPR) Subsidi. Dalam realisasi kredit, terjadi persetujuan kredit dalam pelaksanaannya pihak dan notaris menjelaskan tentang kewajiban-kewajiban yang harus dipenuhi oleh debitur dan debitur menandatangani perjanjian kredit di atas materai Rp.6.000,00. Dalam hal ini terjadi perikatan kredit antara pihak debitur dan pihak bank yang sah secara hukum. Debitur harus menyediakan dana untuk membayar biaya-biaya lainnya. Dalam prosedur realisasi ini sudah baik karena adanya perjanjian hitam di atas putih dilengkapi juga dengan materai sehingga perjajian ini sangat jelas dan di lindungi dengan hukum.

d. Prosedur Pembayaran Angsuran dan Pelunasan Kredit Pemilikan Rumah (KPR) Subsidi. Pada prosedur pembayaran angsuran dan pelunasan kredit, pembayarannya dilakukan dibagian Teller Service, bagian Head Teller mencocokkan pembayaran serta laporan yang diterima dari bagian Teller Service, bagian Kasie Retail Service memeriksa ulang laporan dan jumlah pembayaran dan bagian Bookepping and Control mengentri jurnal umum. Prosedur yang dilakukan Bank sudah baik karena dalam pembayarannya melewati beberapa proses sehingga kecil kemungkinan jika terjadi kesalahan dalam pembayaran angsuran. Pada prosedur pembayaran angsuran dan pelunasan kredit bisa dilakukan dengan 6 cara yaitu, 1) pembayaran angsuran dipotong langsung dari gaji, 2) pembayaran langsung ke loket, 3) pembayaran melalui ATM Batara, 4) pembayaran dengan transfer, 5) pembayaran melalui kantor pos dan 6) pembayaran dengan cara pemindahbukuan. Dalam prosedur pembayaran angsuran dan pelunasan ini sudah baik karena banyak cara yang ditawarkan oleh bank untuk pihak debitur sehingga debitur bisa dengan mudah membayar angsurannya.

Analisis Penyebab Kredit Macet pada Kredit Pemilikan Rumah (KPR) Subsidi. Dalam pemberian Kredit Pemilikan Rumah (KPR) Subsidi mempunyai suatu masalah yaitu kredit macet, dalam hal ini yang menyebabkan terjadinya kredit macet pada Kredit Pemilikan Rumah (KPR) Subsidi di Bank Tabungan Negara cabang Manado yaitu pihak eksternal (debitur). Dari data yang diperoleh dari penelitian ini peneliti dapat mengetahui apa saja yang menjadi faktor terjadinya kredit macet dalam pemberian Kredit Pemilikan Rumah (KPR) Subsidi pada Bank Tabungan Negara. Penyebab terjadinya kredit macet yaitu :

1. Debitur Sakit. Dalam faktor ini pada saat mengajukan permohonan kredit debitur sudah sesuai dengan kriteria yang berhak menerima Kredit Pemilikan Rumah (KPR) Subsidi dan mampu membayar angsuran yang telah disepakati dengan pihak bank. Tapi pada saat setelah pemberian kredit dilakukan debitur sakit sehingga debitur tidak lagi mampu membayar angsuran yang telah disepakati sebelumnya. Dan faktor ini salah satu penyebab terjadinya kredit macet.

2. Debitur sudah tidak memiliki pekerjaan. Dalam faktor ini pada saat mengajukan kredit debitur berhak menerima Kredit Pemilikan Rumah (KPR) Subsidi karena debitur sudah sesuai dengan kriteria yang berhak menerima KPR Subsidi. Tapi pada saat setelah pemberian kredit dilakukan pihak debitur tidak lagi memiliki pekerjaan sehingga debitur mengalami penurunan ekonomi dalam hal ini debitur tidak lagi mampu membayar angsuran Kredit pemilikan Rumah (KPR) Subsidi yang telah disepakati sebelumnya sehingga menyebabkan kredit macet. 
3. Rumah tidak standar. Dalam faktor ini pada saat mengajukan kredit debitur tidak melakukan survey pada rumah yang akan di ajukan sehingga debitur tidak mengetahui bagaimana kondisi rumah yang akan di ajukan. Apakah mengalami kerusakan contohnya: pompa air atau aliran listrik rusak. Sehingga terjadi kredit macet karena debitur tidak ingin membayar angsuran yang telah disepakati sebelumnya dengan alasan rumah yang tidak sesuai standar. Pihak bank tidak memiliki tanggungjawab terhadap hal ini karena ini berhubungan langsung antara debitur dan developer, pihak bank hanya menyediakan dana yang akan dibayarkan kepada pihak developer.

4. Karakter debitur. Dalam faktor ini terjadinya kredit macet karena disebabkan dari karakter debitur yang dengan sengaja tidak ingin membayar angsuran yang telah disepakati walaupun sebenarnya debitur mampu membayar angsuran.

Adapun upaya yang dilakukan pihak BTN untuk menyelesaikan kredit macet yang terjadi pada Kredit Pemilikan Rumah (KPR) Subsidi yaitu :

1. Penagihan. Dalam upaya ini pihak bank melakukan penagihan terhadap debitur yang mengalami penunggakan jika debitur belum lagi membayar tagihan tersebut maka pihak bank membuat surat peringatan, surat perinngatan terdiri dari : (a) Surat Peringatan I (SPI), (b) Surat Peringatan II (SP-II), dan (c) Surat Peringatan III (SP-III). Surat peringatan ini untuk memeperingati debitur agar membayar tagihan, dengan adanya surat-surat ini pihak bank memberikan waktu kepada debitur agar bisa melunasi tagihannya. Jika surat peringatan I, II, dan III telah diberikan kepada debitur namun debitur masih saja belum melunasi tagihannya maka pihak bank akan menindak lanjuti pada upaya selanjutnya.

2. Lelang. Dalam hal ini pihak bank akan melelang rumah yang telah dimiliki debitur setelah surat peringatan I, II, dan III telah diterima oleh debitur namun debitur tetap tidak membayar tagihannya. Ini merupakan upaya terakhir yang dilakukan pihak bank untuk mengatasi debitur yang mengalami kredit macet.

\section{KESIMPULAN DAN SARAN}

\subsection{Kesimpulan}

Menurut dari data-data yang didapat dan hasil yang sudah dipaparkan, penulis membuat kesimpulan, yaitu:

1. Bank Tabungan Negara cabang Manado telah melaksanakan sistem pemberian Kredit Pemilikan Rumah (KPR) Subsidi dengan baik dan benar, sudah sesuai dengan standar yang ditetapkan, ditambah dengan adanya sistem E-Loan yang dapat memudahkan dalam proses pemberian kredit dan pengambilan keputusan, sehingga keputusan yang diambil bisa lebih efektif dan efisien dari pada sistem yang tidak menggunakan E-Loan.

2. Dalam proses pelaksanaan pemberian Kredit Pemilikan Rumah (KPR) Subsidi dilakukan. secara terpisah dalam setiap bagian, sehingga pemberian Kredit Pemilikan Rumah (KPR) Subsidi yang dilakukan sudah baik. Prosedur-prosedur pada tiap sistem kredit yaitu prosedur permohonan KPR Subsidi, prosedur pengambil keputusan pemberian KPR Subsidi, dan prosedur pembayaran angsuran KPR Subsidi sudah teratur dengan baik dalam pelaksanaanya.

3. Pelaksanaan pengendalian internal yang ada di Bank Tabungan Negara cabang Manado pada Kredit Pemilikan Rumah (KPR) Subsidi sudah cukup baik karena dilaksanakan sesuai dengan standar operasional prosedur dan kebijakan direksi. Dengan mengikuti struktur organisasi perusahaan, dimana tugas dan tanggungjawab serta wewenang yang dilakukan dengan cara terstruktur sehingga program-program yang dijalankan bisa berjalan dengan baik dan memiliki otoritas yang jelas, dan terdapat pemisahan fungsi yang cukup baik dalam melaksanakan pengendalian internal. Adanya informasi yang di dapat sangat akurat dan komunikasi yang baik antara pihak bank, debitur, dan notaris dalam hal pemberian Kredit Pemilikan Rumah (KPR) Subsidi. 
4. Dalam sistem dan prosedur pemberian Kredit Pemilikan Rumah (KPR) Subsidi yang ada pada Bank Tabungan Negara mempunyai suatu masalah yaitu kredit macet. Yang menyebabkan terjadinya kredit macet karena adanya beberapa faktor, seperti faktor debitur sakit, faktor debitur tidak memiliki pekerjaan, rumah tidak standar, dan karakter debitur. Dari faktor-faktor penyebab ini Bank Tabungan Negara cabang Manado melakukan upaya untuk menanggulangi kredit macet tersebut dengan cara melakukan tagihan yang di ikuti dengan surat peringatan sebanyak tiga kali dengan waktu yang sudah ditentukan oleh pihak bank dan upaya terkahir yakni bank melakukan pelelangan terhadap rumah yang belum juga membayar angsuran setelah diberikannya surat peringatan yang ketiga.

\subsection{Saran}

Sesuai dengan hasil penelitian yang telah dilakukan, penulis ingin memberikan saran agar dapat lebih meningkatkan kinerja sistem Kredit Pemilikan Rumah (KPR) Subsidi pada Bank Tabungan Negara cabang Manado. Maka penulis ingin memberikan saran sebagai berikut:

1. Untuk mengurangi kredit macet yang ada di Bank Tabungan Negara cabang Manado, sebaiknya bank saat melakukan perjanjian kredit dengan pihak debitur mengingatkan lagi bahwa rumah yang ingin dibeli oleh debitur agar dapat mengeceknya terlebih dahulu, agar rumah yang dibeli sudah diketahui kondisinya. Sehingga dengan ini dapat meminimalisir kredit macet yang terjadi akibat faktor rumah tidak standar.

2. Untuk mengurangi kredit macet yang terjadi dikarenakan faktor kesengajaan yang dilakukan pihak debitur yang tidak ingin membayar angsurannya, maka sebaiknya pihak Bank Tabungan Negara cabang Manado membuat syarat khusus bagi para pemohon kredit yang memiliki gaji tetap dari tempat kerja diwajibkan untuk angsurannya di potong langsung dari gaji debitur tersebut dan juga pihak Bank Tabungan Negara sebaiknya membuat sanksi tegas bagi debitur yang termasuk dalam kredit macet, sanksi berupa tidak akan memberikan kredit dalam bentuk apapun kepada debitur yang tidak melunasi angsurannya atau debitur yang mengalami kredit macet. Sehingga dengan adanya syarat dan sanksi ini dapat memperkecil kemungkinan terjadinya kredit macet terutama kredit macet yang disebabkan oleh faktor karakter debitur yang dengan sengaja tidak membayar angsuran meskipun debitur sebenarnya mampu membayarnya.

\section{DAFTAR PUSTAKA}

Arens, A A. Elder, R J. dan Beasly, M S. 2015. Auditing and Assurance Service an Integrated Approach. 15th ed. Pearson International Edition. New Jersey.

Committee of Sponsoring Organization of the Treadway Commission (COSO). 2013. Internal Control - Integrated Framework: Executive Summary. Durham. North California.

Ikatan Bankir Indonesia. 2015. Bisnis Kredit Bermasalah. PT. Gramedia Pustaka Utama. Jakarta.

Ismail. 2013. Manajemen Perbankan. Edisi Ketiga. Kencana. Jakarta.

Kasmir. 2014. Dasar-Dasar Perbankan. Edisi Revisi. PT Raja-Grafindo Persada. Jakarta.

Krismiaji. 2015. Sistem Informasi Akuntansi. Edisi Keempat. UPP STIM YKPN. Yogyakarta. Latdjamudin, A. 2013. Analisi Dan Desain Sistem Informasi. Graha Ilmu. Yogyakarta.

Mulyadi. 2016. Sistem Akuntansi. Edisi Keempat. Salemba Empat. Jakarta.

Peraturan Menteri Pekerjaan Umum dan Perumahan Rakyat Republik Indonesia Nomor 21/PRT/M/2016. Kemudahan dan/atau Bantuan Perolehan Rumah Bagi Masyarakat Berpenghasilan Rendah. 14 Juni 2016. Jakarta. 
Pontoh, W. 2013. Akuntansi Konsep dan Aplikasi. Halaman Moeka. Jakarta.

Romney, M. dan Steinbart, P. 2015 Sistem Informasi Akuntansi. Edisi Ketigabelas. Salemba Empat.

Satria, M R. 2018. Analisis Perbandingan Pemberian Kredit Kepemilikan Rumah (KPR) Pada Bank Konvesional Dengan Pembiayaan Murabahah (KPR) Pada Bank Syariah (Studi Kasus Pada Bank BJB Dengan Bank BJB Syariah). Amwaluna Jurnal Ekonomi dan Keuangan Syariah. Vol. 2 No. 1.

Susanto, A. 2013. Sistem Informasi Akuntansi. Lingga Jaya. Bandung.

Undang-Undang Republik Indonesia Nomor 1 Tahun 2011. Perumahan Dan Kawasan Pemukiman. 12 Januari 2011. Lembaran Negara Republik Indonesia Tahun 2011 Nomor 7. Jakarta. 